\title{
Lokalizacja firm i zachowania przestrzenne pracowników sektora informatycznego (na przykładzie poznańskiego obszaru metropolitalnego)
}

We współczesnym świecie szczególnego znaczenia nabierają obszary, które związane są z kształtowaniem się gospodarki informacyjnej i społeczeństwa informacyjnego. Stwierdzenie to dotyczy różnych skal przestrzennych. Celem artykułu jest:

- w płaszczyźnie teoretycznej - próba odpowiedzi na pytanie, jak rozwój sektora informatycznego wpływa na zmianę tradycyjnych koncepcji lokalizacji działalności gospodarczej i rozwoju regionalnego;

- w płaszczyźnie empirycznej - analiza stanu, dynamiki i struktury przestrzennej sektora informatycznego (a ściślej teleinformatycznego) oraz zachowań przestrzennych jego pracowników na przykładzie poznańskiego obszaru metropolitalnego.

Analiza ta opiera się na wynikach międzynarodowego projektu badawczego ACRE (Accommodating Creative Knowledge: Competitiveness of European Metropolitan Regions within the Enlarged Union - Wykorzystanie kreatywnej wiedzy: konkurencyjność europejskich regionów metropolitalnych w rozszerzonej Unii) i osadzona jest w szerszej koncepcji rozwoju sektora kreatywnego (Stryjakiewicz 2008a, 2008b). Z tego względu w celu zachowania zgodności z terminologią przyjmowaną w projekcie w empirycznej części niniejszego artykułu (a zwłaszcza tam, gdzie odwołuję się bezpośrednio do wyników projektu) używam pojęć: ,„sektor kreatywnej wiedzy” (które utożsamiam z pojęciem sektora kreatywnego) oraz „technologie informacyjno-komunikacyjne” (ICT), w skład których obok branż stricte informatycznych wchodzi również telekomunikacja.

\section{JAK ROZWÓJ SEKTORA INFORMATYCZNEGO WPŁYWA NA ZMIANĘ TRADYCYJNYCH KONCEPCJI LOKALIZACJI DZIAŁALNOŚCI GOSPODARCZEJ I ROZWOJU REGIONALNEGO?}

Rozwój sektora informatycznego pociaga za sobą m.in.:

- zmianę tradycyjnych czynników lokalizacji działalności gospodarczej;

- zmianę ścieżek rozwoju regionalnego (development paths);

- zmianę polityki regionalnej i lokalizacyjnej.

W najbardziej ogólnym ujęciu można powiedzieć, że zmiana czynników lokalizacji wyraża się w spadku znaczenia czynników „kosztowych” (jak np. koszt transportu, koszt pracy, podatki), a wzroście roli elementów jakościowych kapitału ludzkiego, takich jak: kreatywność, wiedza (skodyfikowana i ukryta), wysokie kwalifikacje, zdolność przystosowywania 
się do szybkich zmian, otwartość na nowe pomysły, umiejętność współpracy. Należy w tym miejscu zgodzić się z tezą Crone'a (2003), że w sektorze informatycznym przepływ idei jest równie ważny jak przepływ kapitału fizycznego.

Sektor informatyczny jest ważnym elementem kształtowania się regionów kreatywnych, których ścieżki rozwoju są odmienne od ścieżek rozwoju regionów tradycyjnych. Różnicę tę ilustruje ryc. 1 .

\section{Tradycyjne koncepcje}

tworzenie dobrego klimatu do przyciagania biznesu (np. niskie podatki, rozwinięta infrastruktura materialna)

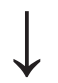

powstawanie nowych miejsc pracy i wysokie tempo wzrostu gospodarczego

migracje (napływ) ludności

\section{Nowe koncepcje}

tworzenie dobrego klimatu do przyciagania kreatywnych ludzi (np. atrakcyjność miejsc zamieszkania i przestrzeni publicznej, atmosfera otwartości i tolerancji)

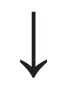

migracje ludzi kreatywnych do atrakcyjnych regionów/miast

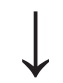

powstawanie nowych miejsc pracy i wysokie tempo wzrostu gospodarczego w wyniku efektu mnożnikowego

Ryc. 1. Zmiana ścieżek rozwoju regionalnego

Źródło: opracowanie własne

Już E.M. Hoover (1948, tłum. pol. 1962) zwracał uwagę, że w polityce lokalizacji działalności gospodarczej należy troszczyć się o wysoką jakość życia, która zachęci do zamieszkania w danym miejscu ludzi o najwyższych kwalifikacjach, a w ślad za nimi przyjdą wartościowe miejsca pracy. Również T.N. Clark (2003) wskazuje na związek między jakością życia, przyciaganiem ludzi, których zaliczamy do klasy twórczej, a lokalizacją działalności gospodarczej i rozwojem miast (por. Dziemianowicz 2008, s. 63). Te stwierdzenia wydają się znajdować potwierdzenie i rozwinięcie w koncepcjach R. Floridy $(2002,2005)^{1}$. Boschma i Fritsch (2008, s. 286) streszczają je następująco:

Florida kładzie nacisk na społeczno-kulturalne podstawy rozwoju regionalnego [...]. Powstający w efekcie „dobry klimat dla ludzi” wytwarza, zdaniem Floridy, otoczenie sprzyjające wzrostowi gospodarczemu w regionach. Tego rodzaju tezy stoją w pewnej sprzeczności z konwencjonalnymi przekonaniami, zgodnie z którymi otoczenie sprzyjające wzrostowi powinno się cechować „dobrym klimatem dla biznesu”, czyli przede wszystkim niskimi podatkami i dobrą infrastrukturą materialną. Tymczasem Florida stawia te zależności „na głowie”: tym, co przyciaga ludzi kreatywnych, a wraz z nimi innowacyjne przedsięwzięcia gospodarcze, jest „,dobry klimat dla ludzi”. Klasa kreatywna wcale nie migruje do określonych miejsc tylko z powodu wysokiego tempa wzrostu

\footnotetext{
${ }^{1}$ Koncepcje te omówiłem szerzej w swych wcześniejszych pracach (Stryjakiewicz 2008a, 2008b).
} 
gospodarczego. Zależność jest wręcz przeciwna - wysokie tempo wzrostu gospodarczego jest efektem obecności w określonych miejscach dużych skupisk przedstawicieli klasy kreatywnej. Florida twierdzi więc przewrotnie, że to nie ludzie migrują za praca, lecz praca za ludźmi.

Konsekwencją powyższej zmiany paradygmatu rozwoju regionalnego są zmiany polityki regionalnej i lokalizacyjnej. Zmiany te przejawiają się m.in. w coraz większym nacisku na społeczno-kulturowe i edukacyjne podstawy rozwoju regionalnego, a także w coraz silniejszym związku procesów rozwoju społeczno-gospodarczego z procesami mobilności przestrzennej. Następuje wzrost znaczenia tzw. miękkich czynników lokalizacji, przyciągających klasę twórczą do określonych miejsc (np. dziedzictwo kulturowe, zróżnicowanie etniczne, klimat otwartości i tolerancji, atrakcyjność miejsc zamieszkania i przestrzeni publicznej, jakość szkolnictwa wyższego i systemu edukacyjnego, poczucie bezpieczeństwa). Kształtowanie tzw. przestrzeni kreatywnych staje się ważnym zadaniem polityki regionalnej i polityki miejskiej.

Można zatem stwierdzić, że wyłania się nowa teoria lokalizacji, w której „nakładają się” kwestie związane z czynnikami lokalizacji firm, jakością życia, przyciąganiem i zachowaniami klasy kreatywnej oraz konkurencyjnością (por. McCann i Sheppard 2003, Clark 2003, Swianiewicz 2005). Wszystkie te elementy ujęte są w koncepcji międzynarodowego projektu badawczego ACRE, którego krótki zarys zostanie przedstawiony poniżej.

\section{BADANIA SEKTORA INFORMATYCZNEGO W RAMACH PROJEKTU ACRE}

Sektor informatyczny, a ściślej teleinformatyczny (ICT) zajmuje istotne miejsce w tworzeniu tzw. sektora kreatywnej wiedzy, który jest przedmiotem badań prowadzonych w ramach międzynarodowego projektu ACRE. Projekt finansowany jest ze środków VI. Programu Ramowego Unii Europejskiej, a przewidywany czas jego realizacji wynosi 4 lata (20062010). W skład konsorcjum wchodzi 13 partnerów z różnych części Europy (Amsterdam, Barcelona, Birmingham, Budapeszt, Dublin, Helsinki, Lipsk, Mediolan, Monachium, Poznań, Ryga, Sofia, Tuluza). Reprezentują oni różne typy obszarów metropolitalnych: położonych w „starych” i „nowych” państwach członkowskich UE, pełniących funkcje stołeczne lub pozbawionych tych funkcji, o różnych ścieżkach rozwojowych, długiej lub krótkiej tradycji występowania sektora kreatywnego. Koordynatorem projektu jest prof. dr Sako Musterd z Amsterdamskiego Instytutu Badań nad Rozwojem Metropolitalnym i Międzynarodowym (Amsterdam Institute for Metropolitan and International Development Studies - AMIDSt), a jego kierownikiem ze strony polskiej - autor niniejszego artykułu. Wykonawcami projektu jest zespół pracowników Instytutu Geografii Społeczno-Ekonomicznej i Gospodarki Przestrzennej Uniwersytetu im. Adama Mickiewicza w Poznaniu².

Głównym celem badawczym projektu jest próba odpowiedzi na pytanie: jakie czynniki stymulują kształtowanie się i rozwój regionów kreatywnych w rozszerzonej Unii Europejskiej? Przedmiotem szczególnego zainteresowania jest rola wymienionych uprzednio czynników miękkich w tym rozwoju.

${ }^{2}$ W skład zespołu badawczego wchodzą: prof. dr hab. Tadeusz Stryjakiewicz (kierownik projektu), prof. UAM dr hab. Tomasz Kaczmarek, prof. dr hab. Jerzy J. Parysek, dr Michał Męczyński, dr Krzysztof Stachowiak, mgr Emilia Grzywińska, mgr Bartosz Stępiński (pomoc techniczna). 
$\mathrm{W}$ celu rozwiązania tak postawionego problemu badawczego $\mathrm{w}$ ramach projektu prowadzone są szerokie badania empiryczne (ankiety, wywiady), obejmujące trzy grupy docelowe: absolwentów szkół wyższych, pracowników i menadżerów zatrudnionych w sektorze kreatywnej wiedzy oraz migrantów zagranicznych przybywających do pracy w tym sektorze. Badania prowadzone są we wszystkich wymienionych wcześniej 13 regionach metropolitalnych Europy według jednolitej metodologii, tak by możliwe było dokonanie porównań międzyregionalnych. Obok porównań międzyregionalnych projekt zakłada również szczegółową analizę procesów zachodzących wewnątrz poszczególnych obszarów metropolitalnych (dotyczących m.in. dynamiki zmian na rynku pracy lub zmian relacji między centrum a strefą podmiejską). Z tego względu wyniki projektu będą miały duże znaczenie dla tworzenia strategii rozwoju sektora kreatywnego (w tym sektora informatycznego) w analizowanych regionach.

Miejsce sektora teleinformatycznego w ramach sektora kreatywnej wiedzy przedstawione jest na ryc. 2, a jego wewnętrzny podział (oparty na definicjach OECD oraz Europejskiej i Polskiej Klasyfikacji Działalności) w tabeli 1.

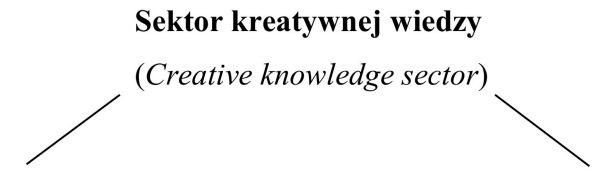

Działalności twórcze (creative industries) [definicja według Brytyjskiego Departamentu

Kultury, Mediów i Sportu (DCMS)]

- reklama

- architektura

- dzieła sztuki

- rzemiosło artystyczne

- wzornictwo i projektowanie mody

- video, film, działalność muzyczna i fotografia

- działalność artystyczna i rozrywkowa

- działalność wydawnicza

- działalność w zakresie oprogramowania

(software)

- radio i telewizja
Działalności o dużym nasyceniu wiedzą (knowledge intensive industries)

- produkcja i usługi w zakresie technologii informacyjno-komunikacyjnych (ICT)

z wyjątkiem oprogramowania

- usługi finansowe

- usługi prawne i inne usługi dla biznesu

(np. konsulting, badania rynku)

- $\mathrm{B}+\mathrm{R}$ i szkolnictwo wyższe

Ryc. 2. Klasyfikacja sektora kreatywnej wiedzy przyjęta w projekcie ACRE

Źródło: Stryjakiewicz (2008a, s. 136)

Realizacja całości projektu składa się z kilku etapów (work packages), są to kolejno:

1. Przegląd literatury i aktualnego dorobku teoretycznego.

2. Analiza dotychczasowych ścieżek rozwoju (development paths) oraz stanu sektora kreatywnego (na podstawie dostępnych danych statystycznych) w analizowanych regionach metropolitalnych.

3. Opracowanie studium porównawczego, zawierającego wnioski na temat podobieństw i różnic między badanymi regionami oraz próba ich klasyfikacji.

4. Określenie znaczenia wybranych grup społecznych (absolwenci szkół wyższych, pracownicy i menadżerowie sektora kreatywnego, migranci - cudzoziemcy) w każdym $\mathrm{z}$ analizowanych regionów. 
Tab. 1. Klasyfikacja sektora ICT

\begin{tabular}{|c|c|c|}
\hline \multirow{17}{*}{$\begin{array}{l}\text { Information \& } \\
\text { Communication } \\
\text { Technology } \\
\text { (adapted from } \\
\text { OECD definition) }\end{array}$} & ICT manufacturing & - \\
\hline & $\begin{array}{l}300 \text { Manufacture of office } \\
\text { machinery and computers }\end{array}$ & $\begin{array}{l}30 \text { Produkcja maszyn biurowych } \\
\text { i komputerów }\end{array}$ \\
\hline & $\begin{array}{l}313 \text { Manufacture of insulated } \\
\text { wire and cable }\end{array}$ & $\begin{array}{l}31,3 \text { Produkcja izolowanych drutów } \\
\text { i przewodów }\end{array}$ \\
\hline & $\begin{array}{l}321 \text { Manufacture of electronic } \\
\text { valves and tubes and other } \\
\text { electronic components }\end{array}$ & $\begin{array}{l}32,1 \text { Produkcja lamp elektronowych } \\
\text { i pozostałych elementów elektronicz- } \\
\text { nych }\end{array}$ \\
\hline & $\begin{array}{l}322 \text { Manufacture of television and } \\
\text { radio transmitters and apparatus for } \\
\text { line telephony and line telegraphy }\end{array}$ & $\begin{array}{l}32,2 \text { Produkcja nadajników telewizyj- } \\
\text { nych i radiowych oraz aparatów dla } \\
\text { telefonii i telegrafii przewodowej }\end{array}$ \\
\hline & $\begin{array}{l}323 \text { Manufacture of television and } \\
\text { radio receivers, sound or video } \\
\text { recording or reproducing apparatus } \\
\text { and associated goods }\end{array}$ & $\begin{array}{l}\text { 32,2 Produkcja nadajników telewizyj- } \\
\text { nych i radiowych urządzeń do rejestra- } \\
\text { cji i odtwarzania dźwięku obrazu oraz } \\
\text { akcesoriów do nich }\end{array}$ \\
\hline & $\begin{array}{l}332 \text { Manufacture of instruments } \\
\text { and appliances for measuring, } \\
\text { checking, testing, navigating and } \\
\text { other purposes except industrial } \\
\text { process control equipment }\end{array}$ & $\begin{array}{l}33,2 \text { Produkcja instrumentów } \\
\text { i przyrządów pomiarowych, kontrol- } \\
\text { nych, badawczych, nawigacyjnych } \\
\text { i pozostałego przeznaczenia, } \\
\text { z wyłączeniem sprzętu do sterowania } \\
\text { procesami przemysłowymi }\end{array}$ \\
\hline & $\begin{array}{l}333 \text { Manufacture of industrial } \\
\text { process equipment }\end{array}$ & $\begin{array}{l}\text { 33,3 Produkcja systemów do sterowa- } \\
\text { nia procesami przemysłowymi }\end{array}$ \\
\hline & ICT Services & - \\
\hline & 642 Telecommunications & 64,2 Telekomunikacja \\
\hline & 72 Computer related activities & \\
\hline & 72.1 Hardware consultancy & $\begin{array}{l}72,1 \text { Doradztwo w zakresie sprzętu } \\
\text { komputerowego }\end{array}$ \\
\hline & $\begin{array}{l}72.2 \text { Software consultancy and } \\
\text { supply }\end{array}$ & $\begin{array}{l}\text { 72,2 Działalność w zakresie } \\
\text { oprogramowania }\end{array}$ \\
\hline & 72.3 Data processing & 72,3 Przetwarzanie danych \\
\hline & 72.4 Database activities & $\begin{array}{l}\text { 72,4 Działalność związana z bazami } \\
\text { danych }\end{array}$ \\
\hline & $\begin{array}{l}72.5 \text { Maintenance and repair of } \\
\text { office, accounting and computing } \\
\text { machinery }\end{array}$ & $\begin{array}{l}72,5 \text { Konserwacja i naprawa maszyn } \\
\text { biurowych, księgujących i sprzętu } \\
\text { komputerowego }\end{array}$ \\
\hline & $\begin{array}{l}72.6 \text { Other computer related } \\
\text { activities }\end{array}$ & $\begin{array}{l}\text { 72,6 Działalność związana } \\
\text { z informatyką, pozostała }\end{array}$ \\
\hline
\end{tabular}


5. Analiza opinii ww. grup społecznych na podstawie badań ankietowych i wywiadów według wspólnych ustaleń metodologicznych $(\mathrm{n}=200$ wywiadów w każdym z regionów).

6. Synteza wyników badań empirycznych i stworzenie raportu integrującego wnioski poszczególnych zespołów badawczych. Przedstawienie zbieżności lub rozbieżności procesów rozwojowych w regionach metropolitalnych Europy Zachodniej, Środkowej i Wschodniej.

7. Opracowanie wskazań dla polityk i strategii rozwoju regionalnego uwzględniających różne ścieżki rozwoju oraz określenie wkładu, jaki mogą wnieść regiony kreatywne w rozwój Europy.

8. Upowszechnienie wyników projektu.

Rezultaty badań prowadzonych w ramach projektu ACRE publikowane są na bieżąco w serii anglojęzycznych raportów, dostępnych również w wersji elektronicznej na stronie http://www2.fmg.uva.nl/acre. Omówienie wyników realizacji pierwszych etapów projektu w języku polskim zawarte jest w pracach Stryjakiewicza (2008a,b) oraz Stryjakiewicza, Męczyńskiego i Stachowiaka (2008). Poniżej zostaną przedstawione jedynie wyniki dotychczasowych badań dotyczące stanu, dynamiki i struktury oraz zachowań przestrzennych pracowników sektora informatycznego w poznańskim obszarze metropolitalnym.

\section{WSTĘPNE WYNIKI BADAŃ DOTYCZĄCE LOKALIZACJI FIRM}

\section{ZACHOWAŃ PRZESTRZENNYCH PRACOWNIKÓW}

\section{SEKTORA INFORMATYCZNEGO W POZNAŃSKIM OBSZARZE METROPOLITALNYM}

Prezentowana analiza opiera się zarówno na danych statystycznych zebranych w Urzędzie Statystycznym w Poznaniu (liczba podmiotów, liczba pracujących), jak i na wywiadach przeprowadzonych w 2007 r. wśród pracowników usług informatycznych.

Obszar poznańskiego obszaru metropolitalnego obejmuje miasto Poznań oraz powiat poznański. Badany sektor został podzielony na działalność produkcyjną (produkcja maszyn biurowych i komputerów) oraz działalność usługową (patrz tab. 1). Jako mierniki działalności przyjęto liczbę pracujących oraz liczbę podmiotów.

Badanie stanu sektora teleinformatycznego (podobnie jak całego sektora kreatywnej wiedzy) natrafia na poważne przeszkody metodologiczne. Statystyki dotyczące zatrudnienia obejmują bowiem tylko podmioty zatrudniające pracowników powyżej 9 osób. Tymczasem w poznańskim obszarze metropolitalnym jednostki mikro, tj. o liczbie zatrudniających mniej niż 9 osób, stanowią ok. 96\% wszystkich podmiotów sektora kreatywnej wiedzy. W związku z tym konieczne wydaje się przeprowadzenie analizy wykorzystującej również wskaźniki oparte na liczbie podmiotów działających w poszczególnych działach.

W przypadku analizy liczby podmiotów Poznań podzielony został na 33 jednostki urbanistyczne na podstawie danych dostarczonych przez Miejską Pracownię Urbanistyczną. Dla analizy liczby pracujących przyjęto podział terytorialny Poznania na 5 dzielnic, co było uwarunkowane dostępnością danych statystycznych tylko w tych jednostkach przestrzennych. Powiat poznański obejmuje 25 jednostek - 10 miast i 15 gmin wiejskich lub miejsko-wiejskich. Łącznie poznański obszar metropolitalny podzielony został na 58 jednostek (31 w analizie liczby pracujących), dla których obliczono odpowiednio liczbę podmiotów sektora kreatywnej wiedzy oraz liczbę pracujących w tym sektorze, a następnie wskaźniki gęstości. 
Do porównań dynamicznych wzięto pod uwagę lata 2001 i 2005 . Wybór roku $2001 \mathrm{r}$. wynikał z wprowadzenia $\mathrm{w}$ tym roku nowej klasyfikacji działalności gospodarczej przez Główny Urząd Statystyczny. Z powodu tej zmiany dane z lat wcześniejszych nie byłyby w pełni porównywalne z danymi z $2005 \mathrm{r}$.

Podstawowe charakterystyki statystyczne dotyczące firm sektora ICT zamieszczone są w tabelach 2 i 3, natomiast jego strukturę przestrzenną przedstawiają ryciny 3-5 (wykonane przez K. Stachowiaka).

Tab. 2. Struktura firm sektora teleinformatycznego w poznańskim obszarze metropolitalnym

\begin{tabular}{l|c|c|c|c}
\multirow{2}{*}{} & \multicolumn{2}{|c|}{ Produkcja ICT } & \multicolumn{2}{c}{ Usługi ICT } \\
\cline { 2 - 5 } & $\mathbf{2 0 0 1}$ & $\mathbf{2 0 0 5}$ & $\mathbf{2 0 0 1}$ & $\mathbf{2 0 0 5}$ \\
\hline Liczba firm & 391 & 493 & 1133 & 1903 \\
Zatrudnienie & 3327 & 2693 & 2220 & 5268 \\
\% firm zlokalizowanych w mieście Poznaniu & 89,3 & 80,7 & 82,9 & 79,5 \\
$\begin{array}{l}\text { Udział firm zatrudniających od 1 do 9 osób } \\
\text { (w \%) }\end{array}$ & 89,3 & 91,1 & 98 & 97,1 \\
$\begin{array}{l}\text { Udział firm należących do osób fizycznych } \\
\text { (w \%) }\end{array}$ & 69,6 & 70,2 & 78,2 & 77,6
\end{tabular}

Źródło: dane Urzędu Statystycznego w Poznaniu, obliczenia własne

Tab. 3. Wskaźniki dynamiki sektora teleinformatycznego w poznańskim obszarze metropolitalnym 2001-2005 (2001=100)

\begin{tabular}{c|c|c|c|c|c|c} 
& \multicolumn{3}{|c|}{ Produkcja ICT } & \multicolumn{3}{c}{ Usługi ICT } \\
\cline { 2 - 7 } & Ogółem & $\begin{array}{c}\text { Miasto } \\
\text { Poznań }\end{array}$ & $\begin{array}{c}\text { Powiat } \\
\text { poznański }\end{array}$ & Ogółem & $\begin{array}{c}\text { Miasto } \\
\text { Poznań }\end{array}$ & $\begin{array}{c}\text { Powiat } \\
\text { poznański }\end{array}$ \\
\hline Liczba firm & 126,1 & 121,3 & 150,8 & 168 & 161,1 & 201 \\
Zatrudnienie & 80,9 & 69,1 & 200,3 & $237,3^{*}$ & $234,7^{*}$ & $256,9^{*}$
\end{tabular}

* są to najwyższe wartości wśród wszystkich analizowanych działalności kreatywnych (wartość średnia: 131,9)

Źródło: Urząd Statystyczny w Poznaniu, obliczenia własne 


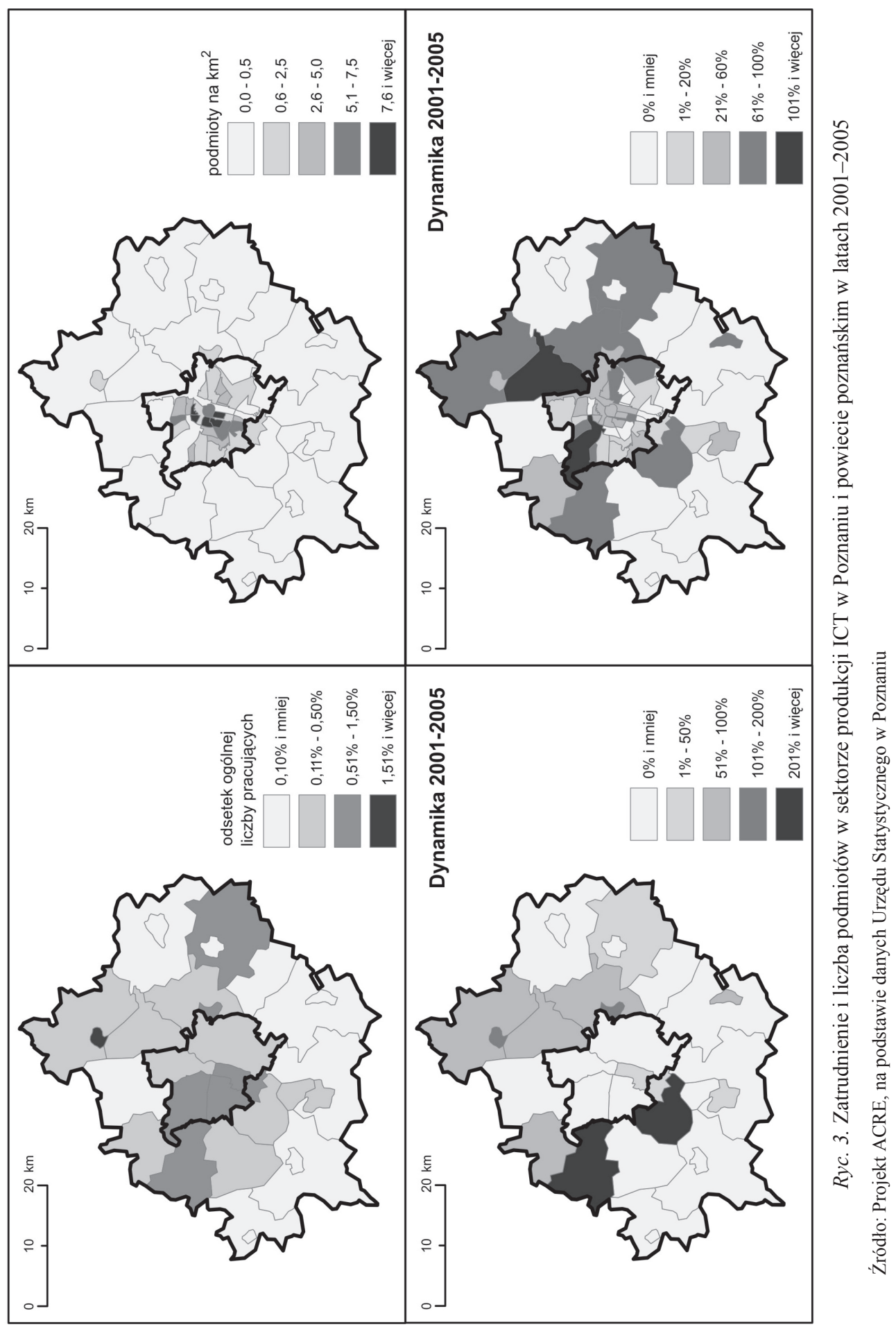




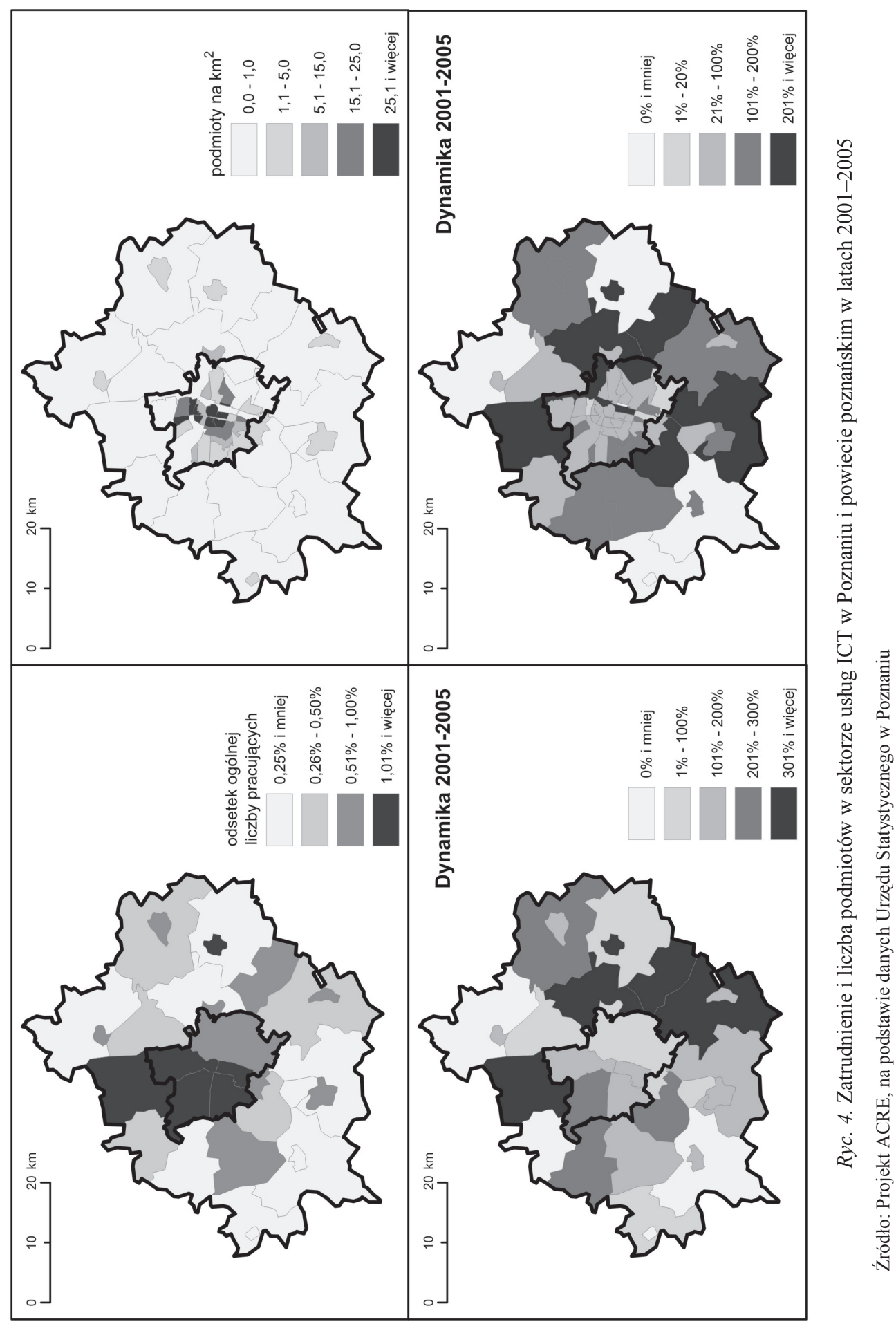




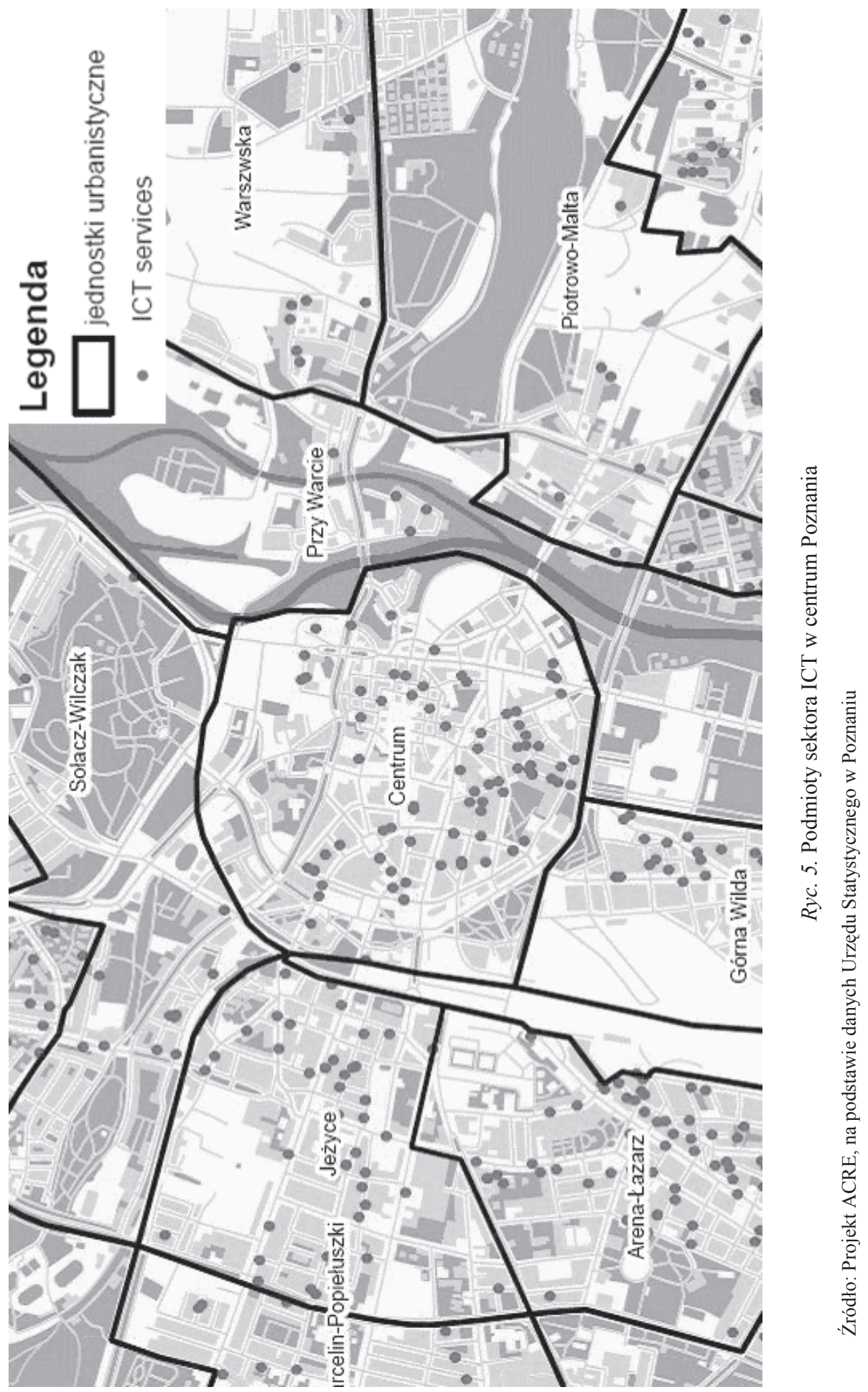


Najważniejsze prawidłowości dotyczące tego sektora sformułować można następująco:

1. Usługi informatyczne i telekomunikacyjne należą do najbardziej dynamicznych działalności gospodarczych.

2. Charakterystyczną cechą analizowanego sektora jest duża liczba firm małych (często opierających się na samozatrudnieniu).

3. Wprawdzie ok. 80\% firm zlokalizowanych jest w Poznaniu, jednak dynamika ich wzrostu jest większa w strefie podmiejskiej, co związane jest z procesem „rozlewania się” miasta (urban sprawl).

4. Centralna i zachodnia część miasta jest bardziej atrakcyjna dla lokalizacji firm sektora informatycznego niż część wschodnia (w której położona jest m.in. Politechnika Poznańska). Efekt spin-off jest jak dotąd stosunkowo niewielki (por. Muent 2000).

Z kolei analiza wybranych cech jakościowych oraz zachowań przestrzennych pracowników sektora informatycznego pokazuje, że ponad $83 \%$ z nich posiada wyższe wykształcenie. Ich obecne miejsce zamieszkania i pracy jest najczęściej ściśle związane nie tyle z miejscem urodzenia, co przede wszystkim z miejscem studiowania. Tę grupę zatrudnionych cechuje duża mobilność (blisko 80\% zmieniało miejsce zamieszkania). Obecnie jednak ich związek z Poznaniem wydaje się silny (tylko 12\% deklaruje chęć zmiany miejsca zamieszkania). Wśród czynników wpływających na jakość ich życia największy problem stanowią dostępność i ceny mieszkań. Pracownicy sektora informatycznego stosunkowo rzadko korzystają $\mathrm{z}$ oferty kulturalnej miasta. Bardziej interesują ich wirtualne formy kultury i rozrywki, w tym tzw. wirtualne kreatywne ,podziemie” (underground).

\section{UWAGI KOŃCOWE}

Wyniki badań zaprezentowane w artykule wskazują na występowanie w poznańskim obszarze metropolitalnym dwóch dróg rozwoju analizowanego sektora. Pierwsza z nich może być określona jako proces doganiania (catching up), wykorzystujący działalność firm transnarodowych i imitujący ścieżkę rozwoju obszarów metropolitalnych Europy Zachodniej. Natomiast druga ze ścieżek ma charakter endogeniczny i opiera się na lokalnym kapitale ludzkim.

Po 1989 r. rozwój sektora ICT uległ gwałtownemu przyspieszeniu w wyniku otwarcia granic kraju. Kolejny impuls stanowiło przyjęcie Polski do Unii Europejskiej w 2004 r. Poznański obszar metropolitalny doskonale wykorzystał walory swego położenia i stał się jednym z liderów transformacji społeczno-ekonomicznej. Okres po 2000 r. cechuje się znaczną dynamiką rozwoju działalności należących do analizowanego sektora. Jest to jednak okres zbyt krótki, a skala procesu zbyt mała, by dokonywać daleko idących uogólnień. Wydaje się jednak, że zaznacza się już pewien efekt mnożnikowy rozwoju sektora informatycznego w poznańskim obszarze metropolitalnym. Jednym z czynników, które zadecydowały o przyznaniu Poznaniowi prawa organizacji światowej konferencji klimatycznej ONZ w 2008 r., była - obok infrastruktury związanej z Międzynarodowymi Targami Poznańskimi - lokalizacja nowoczesnego Centrum Superkomputerowo-Sieciowego. 


\section{Literatura}

Boschma R. A., Fritsch M., 2008. Klasa kreatywna a rozwój regionów w Europie, Problematyka przyszłości regionów, [w:] Jakubowska P., Kukliński A., Żuber P. red., W poszukiwaniu nowego paradygmatu, Ministerstwo Rozwoju Regionalnego, Warszawa.

Clark T. N., 2003, The city as an entertainment machine, Elsevier.

Crone M., 2003, Clustering and cluster development in knowledge-intensive industries: a 'knowledge and learning' perspective on new firm formation and firm-building/firm growth in Ireland's indigenous software industry, $33^{\text {rd }}$ Annual Conference of RSA: British and Irish Section, St Andrews.

Dziemianowicz W., 2008, Konkurencyjność gmin w kontekście relacji władze lokalne - inwestorzy zagraniczni, Wydawnictwa Uniwersytetu Warszawskiego, Warszawa.

Florida R., 2002, The rise of the creative class and how it's transforming work, leisure, community and everyday life, New York.

Florida R., 2005, Cities and the creative class. New York.

Hoover E. M., 1948, The location of economic activity, McGraw-Hill, New York (tłum. pol.: Lokalizacja działalności gospodarczej, Warszawa 1962).

McCann P., Sheppard S., 2003, The Rise, Fall and Rise Again of Industrial Location Theory, „Regional Studies", vol. 37/6-7.

Muent H., 2000, Localised co-operation between small firms in the socio-economic transition process in Poland. Two cases from the Poznan region, [in:] Polish economy in transition: spatial perspectives, Bogucki Wydawnictwo Naukowe, Poznań.

Stryjakiewicz T., Kaczmarek T., Męczyński M., Parysek J.J., Stachowiak K., 2007, Poznań faces the future. Pathways to creative and knowledge-based regions. AMIDSt (Amsterdam Institute for Metropolitan and International Development Studies), Amsterdam.

Stryjakiewicz T., 2008a, Regiony kreatywnej wiedzy - zarys międzynarodowego projektu badawczego ACRE, [w:] Czyż T., Stryjakiewicz T. red., O nowy ksztalt badań regionalnych $w$ geografii i gospodarce przestrzennej, Biuletyn KPZK PAN, z. 237.

Stryjakiewicz T., 2008b, Rozwój sektora kreatywnego w regionach metropolitalnych, [w:] Stryjakiewicz T., Parysek J.J. red., Region społeczno-ekonomiczny i rozwój regionalny, Bogucki Wydawnictwo Naukowe, Poznań.

Stryjakiewicz T., Męczyński M., Stachowiak K., 2008, Sektor kreatywnej wiedzy w Poznaniu i powiecie poznańskim $w$ świetle wyników międzynarodowego projektu badawczego ACRE, [w:] Kaczmarek T., Mizgajski A. red., Powiat poznański. Jakość przestrzeni i jakość życia, Bogucki Wydawnictwo Naukowe, Poznań.

Swianiewicz P., 2005, Nowe interpretacje teoretyczne polityki miejskiej, „Studia Regionalne i Lokalne”, nr 4.

\section{Location of firms and spatial behaviour of employees of the IT sector (the case of the Poznań metropolitan area)}

In the contemporary world, areas characterised by the development of the information economy and society are of particular importance. This article has two goals: a theoretical and an empirical one. From a theoretical perspective, an attempt is made to answer the question of how the growth of the IT sector changes the traditional concepts of industrial location and regional development. The empirical part presents the preliminary results of a research carried out under the international project "Accommodating Creative Knowledge: Competitiveness of European Metropolitan Regions within the Enlarged Union" (ACRE). They show the state, dynamics and spatial structure of the analysed sector 
as well as the spatial behaviour of its employees in the Poznan metropolitan area. The article concludes with a distinction of two development pathways of the IT sector: catching up with the more advanced Western economies and societies, and utilising the endogenous human capital.

prof. dr hab. Tadeusz Stryjakiewicz

Uniwersytet im. Adama Mickiewicza w Poznaniu

Instytut Geografii Społeczno-Ekonomicznej i Gospodarki Przestrzennej

Zakład Polityki Regionalnej i Integracji Europejskiej

e-mail: tadek@amu.edu.pl 